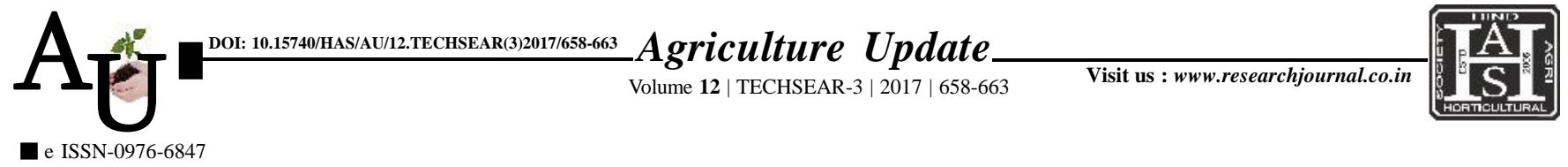

\title{
Research Article: Performance of pre and post emergence herbicides on weed dynamics in tomato cV. ARKA VIKAS
}

\author{
M. VENKATESWARA REDDY, K. UMAJYOTHI, K. SASIKALA, P. SYAM \\ SUNDAR REEDDY AND K.UMAKRISHNA
}

Article Chronicle:

Received :

10.07.2017;

Accepted :

25.07.2017

KEY Words:

Pendimethalin,

Oxyflourfen,

Imazethapyr,

Quizalofopethyle

tomato
Author for correspondence:

\section{VENKATESWARA}

\section{REDDY}

College of Horticulture and Research Institute, Venkataramannagudem, WEST GODAVARI (A.P.)

INDIA

Email : reddymanukonda 1973@gmail.com

See end of the article for authors' affiliations
SUMMARY : A fieid experiment was conducted to study the performance of pre and post emergence herbicides on weed dynamics in Tomato cv. ARKA VIKAS during Rabi 2011-12 and 2012-13. The experiment consisted of 10 treatments of Pre and post emergenceherbicides (Pendimethalin, Oxyflourfen, Imazethapyr and Quizalofop ethyle) and their combinations which were replicated in Randomized Block Design. All the weed control treatments significantly reduced the density of weeds and weed dry matter effectively. Pre emergence herbicides coupled with Quizalofop ethyle found to be onpar with Hand weeding. Though imazethapyr apllied as post emergence, effectively controls the weeds but found to be extremely toxic to the crop. The maximum yield of tomato was recorded with Hand weeding, which is similar to the application of pre emergence herbicides combined with Quizalofop ethyle @ 75g a.i per ha.

How to cite this article : Reddy, M. Venkateswara, Umajyothi, K., Sasikala, K., Reeddy, P. Syam Sundar and Umakrishna, K. (2017). Performance of pre and post emergence herbicides on weed dynamics in tomato cv. ARKA VIKAS. Agric. Update, 12(TECHSEAR-3) : 658-663; DOI: 10.15740/HAS/AU/12.TECHSEAR(3)2017/658663. 